\title{
Muuseumid ja pärand: inimesekeskse pärandihalduse poole
}

\author{
Kurmo Konsa \\ Kaie Jeeser
}

\section{Sissejuhatus}

Kuna muuseumid ja pärand on lahutamatult seotud, siis on muuseumide määratlemise üheks oluliseks tunnuseks alati nende seos pärandiga. Kuigi muuseumid on per se pärandiinstitutsioonid, on uuringuid, mis vaatleksid muuseumide ja pärandi vahelisi seoseid, vähe (Alivizatou 2008; Candlin 2012; Lorente 2012; Babić 2016). ${ }^{1} \mathrm{Nii}$ museoloogia kui ka pärandiuuringute (sh kriitiliste pärandiuuringute) valdkonnad on huvitaval kombel arenenud paralleelselt, kuid üksteist peaaegu käsitlemata. ${ }^{2}$ Museoloogia on pärandi mõistesse suhtunud teatud ettevaatuse ja isegi eelarvamusega ning pärandiuuringud on käsitlenud muuseume lihtsalt kohana, kus leidub pärandit (Watson Barnes jt 2019: xxii-xxiii) Samas rõhutavad mitmed uurijad mõlema valdkonna n-ö sildamise ja kooskäsitlemise vajadust, sest see pakuks nii uusi teoreetilisi võimalusi kui ka praktilisi lahendusi pärandihalduse 
edendamiseks (Babić 2016). Rakenduslikuma külje pealt tuleb mainida, et Eestis on praegu kavas mõlemat valdkonda tihedamalt integreerida ning sellega seoses on kindlasti vaja mõistesüsteeme kooskõlastada.

Selles artiklis anname pärandiuuringute vaate muuseumidele, kasutades analüüsiks kolme mõõdet: pärandiobjekte, ühiskonna tasandeid ja pärandihaldusprotsesse. Püüame leida vastuseid järgmistele küsimustele: kas muuseumid ja museoloogia ning pärandiuuringud käsitlevad pärandit ühistest alustest lähtudes ehk kas pärandiobjektide ja -nähtuste käsitlusvaldkonnad on kattuvad ja kui, siis millisel määral; milline on muuseumide tegutsemishaare lähtudes ühiskonna organiseerituse tasemest; millised on pärandihaldusprotsesside paradigmad muuseumides. Meie eesmärk on esitada kontseptuaalne raamistik, mis võimaldaks paremini välja tuua seoseid pärandi ja muuseumide vahel ning looks aluse pärandiuuringute ja museoloogiliste teoreetiliste mõistete seostamiseks.

\section{Pärandi mõõtmed ja muuseumid}

Muuseumide ja pärandi suhete analüüsimiseks kasutame, nagu öeldud, kolme mõõdet:

- pärandiobjektid ja -nähtused ehk mida pärandina käsitletakse;

- pärandiobjektide ja -nähtuse käsitlemise ühiskondlikud tasandid ehk kes pärandit käsitlevad;

- pärandihalduse paradigmad ehk kuidas pärandit käsitletakse. Sarnast raamistikku on kasutatud pärandiküsimuste analüüsimisel (Konsa 2014: 45-55) ning meie arvates haarab see pärandi ja muuseumide olulisemad kokkupuutepunktid ning võimaldab võrrelda neid valdkondi ühistest printsiipidest lähtuvalt. Varasemas artiklis (Konsa 2014) kasutatud väärtuste dimensiooni oleme selles artiklis kitsendanud, keskendudes pärandihaldusele. Vaatleme neid dimensioone veidi lähemalt ning toome empiirilisi näiteid lähtudes Eesti kontekstist.

\section{Pärandina käsitletavad objektid ja nähtused}

Pärandi hulka võivad kuuluda mitmesugused objektid ja nähtused. See, mida konkreetselt pärandi hulka loetakse, on väga lai: pärandiks võib olla ükskõik mis, mida inimesed selleks peavad (Hewison 1987: 32). Kui vaadata sellise pärandikäsitluse ajaloolist arengut, siis on silmatorkavaks jooneks pärandi hulka loetavate objektide ja nähtuste ringi pidev laienemine, eriti alates 20. sajandi teisest poolest. Algselt

\section{6}


vaid väärtuslikke hooneid ja kunstiteoseid haaranud käsitlusest on nüüdisajaks saanud kõiki inimesega seotud objekte ja looduskeskkonda haarav mõiste. Koos infoühiskonna arenemisega tõuseb järjest olulisemale kohale digitaalne kultuuripärand ja selle säilitamine. Alates 200o. aastate algusest hakati rõhutama pärandi vaimseid aspekte. Pärandi ajaline mõõde on muutunud samuti kõikehõlmavaks. Pärand ei pea enam tingimata pärinema minevikust, vaid tegemist on ka praegusel hetkel loodavate objektide ja nähtustega, millel on kultuuripärandile omased (ka potentsiaalsed) väärtused. Lepitud on tõsiasjaga, et pärandil puuduvad ajalised, ruumilised või sisulised (temaatilised) piirid. Võib kõhklusteta märkida, et pole olemas mitte ühtegi sellist objekti või nähtust, mis ei võiks kuuluda pärandi hulka.

Muuseumid püüavad praktilises tegevuses jõudumööda sammu pidada sellise pidevalt laieneva pärandikäsitlusega. Tekib uut tüüpi muuseume ja laienevad kogutavate objektide tüübid (Knell 2004). Näiteks kui vaadata Tartu Linnamuuseumi kogu, siis varasem kogumine hõlmas eelkõige füüsilisi objekte. Viimastel aastatel on aga üha enam hakatud tähelepanu pöörama vaimse kultuuripärandi kogumisele. Siin võib ära märkida projekti „Üle jõe“ käigus kogutud intervjuud. Samuti proovitakse objektide kogumise kaudu jäädvustada mälestust, meenutust, tunnet, mis on seotud mingi sündmusega. Tartu Linnamuuseumis võib selle näiteks tuua 2014. aasta laulu- ja tantsupeo eelsündmusena toimunud jalgrattaretkega TuleTulemine „Külast külla, käest kätte“ seotud esemete kogumise (foto 17). Nii et kanoonilise pärandivaliku asemel kasutatakse esindava pärandivaliku printsiipi (Konsa 2014: 113). Pärandimõiste laienemine on toonud muuseumi kogumisse ka nn kaasava kogumise.

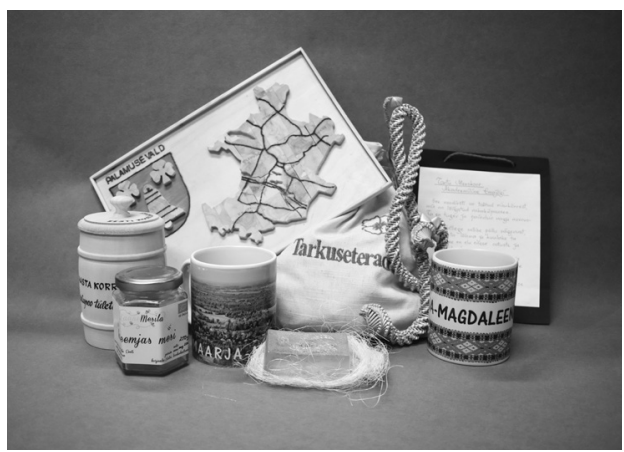

Muuseumid keskenduvad klassikaliselt artefaktide kogumisele, kuid juba muuseumide tekkeajal oli selge, et objektide kõrval tuleb kindlasti koguda ka nendega seotud teavet (Turner 2015). Kui varem keskenduti objektiga vahetult seotud kontekstile (valmistamine, kasutamine), siis nüüd peetakse oluliseks dokumenteerida selle 
kogumisega seotud teave alates ideest kuni kogujateni. Muuseumid, kes hakkasid pöörama tähelepanu looduskeskkonnale kui tervikule ja kogukondade vaimsele kultuuripärandile, sündisid koos uue museoloogia tekkega 1970. aastatel. Prantsuse museoloog Hugues de Varine esitas 1971. aastal ökomuuseumi mudeli, mis rõhutas just nimelt muuseumi seostamist kohaliku keskkonna ja kogukonnaga (Davis 1999: 59-6o). Praktilise poole pealt tähendab pärandi mõiste laienemine üha kasvavat hulka objekte muuseumikogudes ning sellega kaasnevat kasvavat töömahtu seoses nende kirjeldamise ja säilitamisega. Järjest keerukamaks muutuvad küsimused, mida koguda ja mida kõrvale jätta (foto 18). Ühelt poolt mõjutab muuseume surve kajastada maailma ja kultuuri üha põhjalikumalt, teisalt jällegi majanduslik ja laiem halduskeskkond. Pärandi piiride laienemise ja objektide hulga kasvuga kaasneb paratamatult riigi kontrolli suurenemine ja pärandihalduse bürokratiseerumine (Harrison 2013: 55-56).

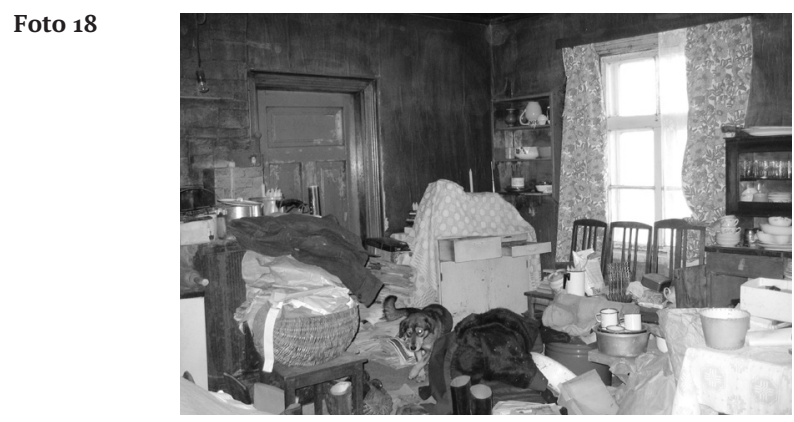

\section{Ühiskonna organiseerituse tasandid}

Ühiskond on organiseerunud üksteist hõlmavate tasanditena alates perekonnast ning lõpetades maailma kui tervikuga. Pärandi haldamisel on ühiskonna organiseerumise tasand üheks oluliseks dimensiooniks, mida kindlasti tuleb arvesse võtta. Mingi objekt või nähtus võib olla pärandiks näiteks kogukonnale, kuid riigi tasandil ei pruugita seda pärandiks lugeda. Pärandi määratlemine, funktsioonid ja haldamine on ühiskonnatasanditel erinevad. Igal tasandil on oma iseloomulik pärandidiskursus ehk viis, kuidas pärandit mõistetakse, sellest räägitakse ning seda sotsiaalses mõttes käsitletakse. Lisaks igale tasandile omasele pärandidiskursusele tajuvad üksikud inimesed samuti pärandit erinevalt. Pärandi käsitlemisel on oluline määratleda, kelle pärandiga on tegemist, kuna pärand saab olla üksnes kellegi pärand (Asworth Tunbridge 1996: 21). Pärandiprobleemide käsitlemisel eristame järgmisi ühiskonnatasandeid: isik ja perekond, kogukond, kohalik omavalitsus, riik (rahvus), riikide ühendused ja maailmapärand. 
Isiklik ja perekondlik tasand. Inimese isikliku pärandi hulka võivad kuuluda perekonnapildid, muusikasalvestised, asjad, suveniirid, sünnimaja, sünnikoht, maastik, mõned perekonnaloos olulised isikud, perepärimus, aga ka näiteks perekonna struktuur ja suhted. Iga inimese ja perekonna hooleks on selle pärandi hindamine ja edasikandmine põlvest põlve. Üks võimalus muude seas on ka isikliku kogu või isegi muuseumi loomine. Selline muuseum võib olla ainult inimese jaoks tähtsate esemete kogu, aga ka laiemale publikule huvipakkuv kollektsioon. Laiemalt tuntud ja eksponeeritud erakollektsioonidest võib näiteks tuua masinamuuseumi (Heino Prost), jalgrattamuuseumi (Valdo Praust), Viinistu kunstimuuseumi (Jaan Manitski). Isiklikest kogudest ja isikumuuseumidest pole ülevaadet ja nende olulisus on täpsemalt analüüsimata. Siiski tegelevad muuseumid üha enam erakogujatega, nii näiteks võimaldavad paljud neist (Eesti Rahva Muuseum, ${ }^{3}$ Tartu Mänguasjamuuseum, Väike-Maarja muuseum jt) kokku panna ja esitleda oma näitusi.

Kogukondlik tasand. Kogukonnana käsitleme inimeste gruppi, kes on vastastikustes püsivates suhetes. Kogukonnas täidetakse vastavalt sotsiaalsetele normidele, huvidele ja väärtustele sotsiaalseid rolle ja taotletakse ühist eesmärki. Eriti tähtis on personaalne suhe konkreetse isiku ja teiste kogukonnaliikmete vahel. Kogukonnad võivad olla määratletud geograafilisel, etnilisel, kultuurilisel, religioossel, sotsiaalsel või majanduslikul alusel. Näiteks võib tuua koolid, ülikoolid, kirikud ja religioossed kogukonnad, naabruskonnad (neighbourhoods), spordiklubid, tudengiorganisatsioonid, klubid, huvigrupid (vt Crow 2011: 74-75).

1960.-1970. aastatel loodud piirkondlikud muuseumid (endised rajooni- ja linnamuuseumid) Eestis muutuvad aina enam kogukonnamuuseumideks, seostades oma tegevust suuremal määral kohalike kogukondade vajaduste ja eelistustega. Tegemist on jällegi üldisema suundumusega anda pärandihaldus riiklikelt süsteemidelt üle kohalikule omavalitsusele ja kogukondadele. Vaja oleks selgemalt määratleda kohaliku taseme pärand ja selle haldamine tuleks administratiivselt ning poliitiliselt anda kohalikele huvigruppidele, samuti tuleks igati soodustada vabatahtlikku ning mittetulunduslikku tegevust.

Paljud organisatsioonid väärtustavad oma pärandit ja peavad seda tähtsaks osaks organisatsioonikultuurist. Eestis on mitmel äriühingul, näiteks Saku ja A. Le Coqi õlletehasel, If Kindlustusel, ASil 
Kalev (Kalevi martsipanimuuseumituba), ülikoolidel (Tartu Ülikooli muuseumid, Tallinna Tehnikaülikooli muuseum) ja valitsusasutustel (Eesti Maanteemuuseum, Eesti Panga muuseum) oma muuseumid.

Kohalik omavalitsus. Kohaliku omavalitsuse üksusteks Eestis on vallad ja linnad, mis moodustavad avaliku halduse süsteemi esmase tasandi. Kohalik omavalitsus teostab järelevalvet oma territooriumil asuvate mälestiste üle ja vastutab muinsuskaitsenõuete täitmise eest (muinsuskaitseseadus 2019). Valla- ja linnavalitsused võivad täita muinsuskaitsealaseid riiklikke kohustusi muinsuskaitseameti ja kohaliku omavalitsuse volikogu vahelise halduslepingu kohaselt. Praegu on selline kohustuste delegeerimine toimunud suuremates linnades (Tallinn, Tartu, Pärnu, Narva ja Haapsalu). Omavalitsus võib määratleda kohaliku taseme pärandit ehituskeskkonna ja loodusobjektide näol. Kohalikud omavalitsused haldavad mitmeid mäluasutusi. Munitsipaalmuuseumidest võib näiteks tuua Kihnu, Liivi ja Narva Muuseumi, Seto Talumuuseumi, Tallinna ja Tartu Linnamuuseumi, Tartu Mänguasjamuuseumi. Kui kohaliku omavalitsuse hallatav muuseum on liitunud muuseumide andmekoguga, siis kohaldub sellele muuseumiseadus.

Riik (rahvus). Kõige enam ongi tuntud mingile rahvusele või riigile omane pärand. Selle tasandi pärandit hakati tänapäevases mõttes ka kõige varem pärandina käsitlema. Rahvus on pärandi käsitlemisel oluline kategooria, kuna etnilisus on seotud kultuuriliste erinevustega ja seetõttu otseselt kultuuripärandiga. Riiklikul tasemel pärandi idee kerkis esile koos rahvusriikide tekkega (Lowenthal 1996). Riikliku taseme pärand on väga selgelt poliitiline idee, väljendades avalike huvide ülimuslikkust eraomandi suhtes. Riik määratleb kultuuripärandit seadusandluse ja institutsioonide kaudu.

Riikide ühendused ja piirkonnad. Pärast Teist maailmasõda hakkas arenema riikideülese pärandi idee. Ühelt poolt leiab see väljenduse mingile riikide grupile omases pärandis ja teisalt maailmapärandis. Näide riikide ühendusest, mille raames väga aktiivselt tegeldakse kultuuripärandiga, on kindlasti Euroopa Liit. Poliitilise, majandusliku ja sõjandusliku alliansina vajab see püsimiseks rohkemat kui ühtset bürokraatiat, poliitilisi eesmärke ja majanduslikke huve. Räägitaksegi vajadusest ühtse Euroopa kultuuri, ajaloo ja identiteedi järele, mille loomisel on kultuuripärandil äärmiselt oluline osa. ELi toimimise lepingus rõhutatakse: „Liit aitab kaasa liikmesriikide kultuuri õitsengule, ühtlasi respekteerides nende rahvuslikku ja regionaalset mitmekesisust ning samal ajal rõhutades ühist kultuuripärandit” (Euroopa Liidu toimimise leping 2010). Seejuures võidakse Euroopa ühist kultuuripärandit käsitleda nii maailmapärandi ühe kategooria kui ka rahvuste ja riikideülese pärandikategooriana (During 2011: 
17-18). Euroopa ühtse pärandi idee edendamiseks on loodud mitmeid muuseume, teiste seas Berliinis asuv Euroopa kultuuride muuseum (Museum Europäischer Kulturen) ja Brüsselis Euroopa ajaloo maja (The House of European History). Tänapäevale on kindlasti iseloomulik riikideülese muuseumidevahelise koostöö tihenemine. Ülioluliseks on muutunud digitaalse teabe ja ühiste veebiplatvormide loomine. Ühtse inforuumi kujundamisega tegeleb aktiivselt Euroopa Liit, kus on näiteks käivitatud kultuuriplatvorm Europeana Collections (www.europeana. eu). See on veebipõhine teenus, mille eesmärgiks on vahendada ühe portaali kaudu avalikkusele Euroopa raamatukogude, muuseumide ja arhiivide digikogusid. Europeana digiraamatukogu põhimõte on koondada ja siduda rahvuslikes kultuuripärandi andmebaasides loodud materjalid üleeuroopalisse keskkonda, et toetada mäluasutusi kogude tutvustamisel. Platvorm pakub juurdepääsu rohkem kui 54 miljonile kultuuriobjektile enam kui 2500 organisatsioonilt.

Maailmapärand. Tegemist on globaalse, kogu maailma haarava ja inimkonnale iseloomuliku pärandiga. Maailmapärandi aluseks on idee kultuuripärandist, mis ületab rahvuslikud, riiklikud ja lokaalsed piirid ning iseloomustab inimkonda tervikuna. Maailmapärandi idee on seotud UNESCO tegevusega ja eriti UNESCO Maailmapärandi programmiga. 1972. aastal võeti vastu UNESCO konventsioon ülemaailmse kultuuri- ja looduspärandi kaitse kohta. See kinnitas rahvusvahelise pärandi olemasolu ja lõi süsteemi selle määratlemiseks. Maailmapärandi kontseptsioon tugineb kultuuri laiale antropoloogilisele käsitlusele ning ühtsete ja universaalsete väärtuste tunnistamisele.

Muuseumide käsitlemisel keskendutakse sageli vaid riikliku taseme muuseumidele. Ühelt poolt on kindlasti põhjuseks see, et need on kõige varem välja kujunenud muuseumiinstitutsioonid, teisalt on selle taseme muuseumid hõlmanud pärandimaastikul kõige mõjuvõimsama positsiooni. Just riiklikud muuseumid määratlevad selle, kuidas inimesed tajuvad ajalugu; kuidas nad seda konstrueerivad, tuginedes muuseumides säilitatavale ja interpreteeritavale pärandile. Muuseumide autoritaarne positsioon hakkas murenema koos uue museoloogia tulekuga. Tõdemus, et muuseumid ei ole ajaloolise tõe neutraalsed vahendajad, vaid nad loovad poliitilisi ja sotsiaalseid käsitlusi maailmast, muutis tegelikult muuseumide positsiooni ühiskonnas märksa olulisemaks. Muuseumidest said institutsioonid, kus huvigrupid esitavad oma arusaamu kultuuri ja ajaloo ning selle kohta, kuidas neid ühiskonnale esitada. Küsimus on ju lõppkokkuvõttes selles, kellel on võim esitada oma nägemus kultuurist (Kreps 2003: 2).

Samas on museoloogiline tähelepanu teiste tasandite muuseumiinstitutsioonide suhtes olnud küllaltki kasin. Eramuuseume ja isiklikke kogusid ei ole museoloogilisest vaatepunktist küllaldaselt 
käsitletud, kuigi isiklik pärand moodustab vägagi suure osa ühiskonnas leiduvast pärandist, samuti on see inimestele kõige omasem ja sageli ka olulisim (Absalyamova ja Absalyamov jt 2015). Samuti on kogukonna ja kohalike omavalitsuste mäluasutused tõusnud museoloogia huviorbiiti alles hiljuti (Candlin 2015). Ning isegi maailmapärandi kontekstis on mäluasutustele hakatud tähelepanu pöörama pigem hilisemal ajal. Mingil kombel on tegemist jällegi ilmse vastuoluga, kuna just mäluasutused on need, mis aitavad maailmapärandit tutvustada ja, mis veelgi olulisem, siduda kohalike kogukondadega (Hayashi 2010). Hinnanguliselt on maailmapärandi objektidega seotud ligikaudu 8000 mäluasutust (Hayashi 2015). Seega on nende kasutamine maailmapärandi edendamiseks vägagi oluline ülesanne. Huvitava projektina võib siin esile tuua nomaadsed muuseumid, mille eesmärgiks ongi siduda maailmapärandi objektid neid ümbritsevate kogukondadega (samas: 129-130).

\section{Pärandihalduse paradigmad}

Tänapäevastes ühiskondades tegeldakse pärandiga teadlikult ja plaanipäraselt. Kõik tegevused, mis on seotud pärandiga, võib võtta kokku mõistega pärandihaldus (heritage management). See haarab põhimõtteid ja tegevusviise, mis on seotud ajaloolise, loodusliku, teadusliku vm väärtusega objektide, paikade ja nähtuste kindlakstegemise, säilitamise, dokumenteerimise, interpreteerimise ja tutvustamisega. ${ }^{4}$ Samamoodi nagu pärand ise on ka pärandihalduse konkreetsed viisid ja meetodid iseloomulikud kindlale sotsiokultuurilisele kontekstile. Pärandi haldamiseks on vaja aru saada sellest, kuidas käsitletakse minevikku nüüdisaegses sotsiaalmajanduslikus ja poliitilises kontekstis ning kuidas see mõjutab pärandi kindlaksmääramist, interpreteerimist, kasutamist ja säilitamist. Paratamatult tuleb rinda pista filosoofiliste, poliitiliste ja majanduslike teemadega, kuna neist sõltub pärandihalduse edukus.

Pärandihaldusprotsesse võib jagada vastavalt sellele, millele need keskenduvad, objekti-, väärtuste- ja inimesekeskseks. Tegemist ei ole kindlas ajalises järjestuses ilmuvate käsitlustega, mis tingimata üksteist välistavad. Kuigi neil on olemas teatud ajaline järjestus,

4 Pärandihalduse mõiste kujunes välja Ameerika Ühendriikides 1960. aastatel. Kriitiliste pärandiuuringute raames on see termin omandanud negatiivse tähendusvarjundi. Viimasel ajal eelistatakse seal kasutada terminit stewardship. Eesti keeles on haldamine küllaltki neutraalse tähendusega, nii et me kasutame seda mõistet. 
kasutatakse neid kõiki sõltuvalt kontekstist käesoleval ajal. See, millist eelistada, sõltub ka käsitlemise eesmärgist.

Objektikesksel lähenemisel (materials based management, objects based management) on haldamisprotsessi keskmeks arusaadavalt objekt ise. Selline käsitlusviis on pärandikäsitluste hulgas kindlasti esmane. Alates kultuuripärandi kontseptsiooni tekkest 18. sajandi lõpul loeti pärandi hulka kuuluvaks silmapaistvad ehitised, kunstiteosed ja muud väärtuslikud ning inimeste geniaalsust iseloomustavad minevikuobjektid. Iseloomulik joon sellise käsitluse korral on pärandi pidamine ajaloolis-sotsiaalsest kontekstist sõltumatuks nähtuseks, mis kannab universaalseid väärtusi. Näiteks väljendub see asjaolus, et kord juba pärandiks määratletu jääb ka selleks. Objektide ja nähtuste väljaarvamine pärandinimestikest on väga harv juhus nii riikliku kui ka rahvusvahelise pärandi korral (Harrison 2013: 166-169).

Igal juhul lähtub objektikeskne pärandihaldus sellest, et ennekõike on oluline säilitada pärandiobjektide materiaalne külg. Objekti füüsiline kahjustumine tähendab minevikku puudutava teabe kadumist. Eesmärgiks on objektide füüsilise terviklikkuse säilitamine, mis tugineb teaduslikele uuringutele. Keel, milles räägitakse, on tänapäeval suuresti teaduse, eriti loodusteaduste keel. Objektikeskse pärandihalduse alusprintsiibid on leidnud kajastust järgmistes rahvusvahelistes dokumentides: ajalooliste mälestiste restaureerimine Ateena hartas (1931), Veneetsia hartas (1961) ja Ülemaailmse kultuuri- ja looduspärandi kaitse konventsioonis (1972).

Suur osa muuseumide tegevusest lähtub objektikesksest lähenemisest. See on täiesti loomulik ja paratamatu, kuna objektid ja kogud moodustavad muuseumi keskme - need eristavadki muuseume teistest mäluasutustest. Samas ei koguta, kirjeldata, uurita ja interpreteerita objekte ju ainult sellepärast, mis need on, vaid hoopiski seetõttu, mida need tähendavad. Oluline ei ole mitte niivõrd füüsiline olemasolu kui just väärtus ja tähendus.

Umbes paar-kolmkümmend aastat tagasi hakkas esiplaanile tõusma pärandi väärtuse küsimus. Sellist väärtust rõhutavat lähenemist nimetatakse väärtusekeskseks haldamiseks (values based management). Objektide olulisus peitubki ju suurel määral nendes väärtuses ja tähenduses, millega inimesed neid seostavad. Pärandiks peetakse objekte või nähtusi alles siis, kui neile on omistatud teatud ajalooline, teaduslik, esteetiline, kunstiline, sotsiaalne või ka mõni muu väärtus (Konsa 2014: 67-82). Just väärtus muudab objekti või nähtuse pärandiks. Väärtused ilmuvad objekti, selle konteksti ja inimeste vastastikuse koosmõju tulemusena. Seega on väärtusekeskse lähenemise korral objekti füüsiline terviklikkus küll endiselt keskmes, kuid arvestatakse ka selle väärtusega. Üks ja seesama objekt võib 
kanda erinevat väärtust: sõltub ajahetkest ja selle omistajatest, milline väärtus objektile või nähtusele antakse ja mida tähtsaks peetakse. Pärandi haldamisega seotud otsustusprotsesse juhivad siiski reeglina eksperdid, kuigi kaasatud on muidki huvigruppe, näiteks kohalikke inimesi, objektide kasutajaid, kunstnikke, omanikke, pärandiobjektide loojaid, muuseumitöötajaid jt. Sellisel juhul räägitaksegi jagatud otsustusprotsessist (shared decison-making). Tänaseks on väärtusekeskne lähenemine pärandihalduses selgelt kanda kinnitanud.

Objektide kogumisel on vaja näidata nende väärtust ja sellest tulenevat olulisust muuseumi jaoks (Muuseumikogu täiendamise ja kultuuriväärtusega asja muuseumisse hoiule võtmise kord 2013). Museaalide väärtuse määratlemine ei ole kaugeltki lihtne ülesanne ja selle juures kerkib hulgaliselt probleeme (vt nt Vint 2017). Pärandi väärtuse väljaselgitamisega on seotud eri huvigrupid, kes omakorda sõltuvad jällegi ühiskonna tasandist, kus pärandit käsitletakse, ja loomulikult iga konkreetse objekti ning nähtuse kontekstist. Isiklikule pärandile annavad väärtuse need isikud, kelle pärandist on jutt. Kogukonnapärandile annab väärtuse see kogukond ise, aga siin tulevad sageli mängu teisedki huvigrupid, nii eksperdid kui ka need, keda antud kogukonna pärand mingil viisil mõjutab. Riikliku pärandi väärtuse väljaselgitajateks on seniajani peamiselt eksperdid ja institutsioonide ametnikud. Laiemate huvigruppide ja kodanike kaasamine riikliku pärandi väärtuse väljatoomisse on eluliselt oluline, et luua inimeste suuremat sidusust pärandiga. Ülemaailmse pärandi väärtuse kindlakstegemine on jäetud täielikult ekspertide ja poliitikute otsustada. Pärandi väärtuse väljatoomisel ei tohi unustada ka sellega seotud võimalikke huvigruppe tulevikus. Pärandiga tegeledes on ju meie eesmärk tagada selle kestvus ajas. Väärtusekeskse haldamise printsiibid leidsid kajastuse Burra hartas (The Burra Charter 1979) ja Nara dokumendis (The Nara Document on Authenticity 1994).

Aga mis siis on ikkagi laiemalt pärandi haldamise eesmärgiks? Lühidalt öelduna tuleb pärandi loomist enam seostada nüüdisaja ja inimestega, kes annavad objektidele väärtuse ja tähenduse. Minevikuinimesed on surnud ja nende väärtusi-tähendusi võime küll uurida, samas kui tulevikuinimeste väärtustest on meil põhimõtteliselt võimatu midagi teada. Nii et üle jäävadki tänapäeva inimesed.

Uut lähenemist, mis seab kogu protsessi keskmesse inimese, tuntaksegi inimesekeskse pärandihaldusena. ${ }^{5}$ Pärand on väga mitmel viisil seotud inimeste eluga - just sellele viitabki selle lähenemise

5 Ingliskeelses teaduskirjanduses kasutatakse termineid peoplesbased mangement, people-centered mangement, public heritage, participatory heritage. 
nimetus. Tähelepanu nihkub sellele, kuidas pärandi loomisprotsess ja selle tulemus mõjutab inimesi. Keskne pole mitte enam materiaalne objekt kui väärtuse kandja, vaid kogukond, kes selle objektile omistab. Tänapäevaste kogukondade heaolu ja väärtushoiakute säilitamine ning kujundamine juhib kogu protsessi. Pärandi loomine algab sellise lähenemise korral väärtuste ja ideede määratlemisest, mida peame oluliseks ja mida tahame edendada. Pärandi loomisel ei määratleta mitte materiaalset objekti ja ka mitte materiaalset objekti, millel on väärtused, vaid sotsiaalseid võrgustikke, mis ühendavad tähenduse ja väärtusega objekte inimeste ning ühiskonnaga. Nii nagu minevik, on ka pärand midagi sellist, mida inimesed pidevalt ümber kujundavad ja loovad. Tegemist on käsitlusega, mis rõhutab antud ajahetkel toimuvat pärandiloomet. Konkreetsed objektid ja nähtused, milles avaldub pärandile omane väärtus, on teisejärgulise tähtsusega. Selles raamistikus on põhirõhk kandunud pärandi sisult või struktuurilt pärandile kui protsessile. Pärand on aktiivne protsess, mille kaudu inimene tajub, mõistab ning kujundab ümber maailma. Pärand ei ole „asi”, vaid kultuuripraktika, mis on tegeleb väärtuste ja arusaamade loomise ning korrastamisega (Smith 2006: 11).

Inimesekeskne lähenemine hakkas tekkima juba enam kui kümme aastat tagasi - 200o. aastatel. Inimesekeskse pärandihalduse printsiibid on leidnud kajastamist järgmistes dokumentides: vaimse pärandi kaitse rahvusvaheline konventsioon (UNESCO 2003), „Faro konventsioon kultuuripärandi väärtustest ühiskonna jaoks“ (Council of Europe Framework Convention 2005), „Säilitamine inimestele: tulevikuvisioon" (National Trust for Historic Preservation 2017). Inimesekeskse lähenemise üha laialdasem levik, millega asetatakse pärand ennekõike kogukondade arengu konteksti, on põhjustanud muutusi pärandivallas - selles, kuidas pärandit luuakse, tajutakse, hinnatakse ja säilitatakse. Lähenemine, mis sai alguse põlisrahvaste pärandi käsitlemisest, on levinud ka klassikaliste pärandobjektide puhul - ehitised, ajaloolised linnad, arheoloogilised paigad jms.

Muuseumides seostub inimesekeskne lähenemine kindlasti nn uue museoloogia tekke ja osalusmuuseumi ideega (vt nt „Osalus muuseumides“ 2014). 1980. aastatel toimusid seoses uue museoloogia tulekuga suured muutused selles, millisena nähti muuseumide rolli ühiskonnas (Rivard 1984; Davis 1999: 54). ${ }^{6}$ Vergo kirjeldas seda kui „laialt levinud rahulolematust vana museoloogiaga nii kutseala sees kui laiemalt. Vana museoloogia häda oli selles, et see keskendus liialt muuseumi meetoditele ning jättis tähelepanuta muuseumide

6 Eesti museoloogiasse ja muuseumidesse jõudsid need muutused alates 200o. aastatest. 
eesmärgid.“ (1989: 3) Museoloogia kriitiline reflekteerimine, mis oli suuresti tingitud kriitilise teooria, kultuuriuuringute ja antropoloogia arengust, tingis nii uut tüüpi muuseumiinstitutsioonide loomise kui ka vanade mudelite ümberkorraldamise. Koostöö muuseumide ja kogukondade vahel muutus üsna tavaliseks nähtuseks.

\section{Kokkuvõte}

Teaduslik käsitlus jaguneb erialadeks, mis käsitlevad maailma eri osi. Ühelt poolt on see triviaalne ja täiesti arusaadav jagamine, teiselt poolt on selge, et reaalne maailm hoolib üsna vähe sellistest jaotustest. Meie arvates on sellesse erialalisse lõksu jäänud ka päranditeadus ja museoloogia. Loodame, et see artikkel aitab natuke murendada neid erialaseid piire ja toob uute vaatenurkade kaudu kasu nii pärandiuuringutele kui ka museoloogiale.

Käsitledes muuseumide ja pärandi seoseid, lähtusime kolmest analüütilisest mõõtmest. Kui nende kolme analüüsi tulemused kokku võtta, võib esile tuua järgmised aspektid. See, mida ühiskond tänapäeval pärandina käsitleb ja mida pärandiks loeb, sõltub ajaloolisest, kultuurilisest ja sotsiaalsest kontekstist ning poliitilisest süsteemist. Pärandiks tunnistamine toimub konkreetsete tegevusviiside kaudu, mis varieeruvad vastavalt kultuurilisele ja ühiskondlikule kontekstile. Objektid, nähtused, paikkonnad ja inimesed ei muutu pärandiks enne, kui inimesed neid sellena tunnistavad. Seega pole pärandit iseenesest mingil olemuslikul, inimeste arvamustest sõltumatul kujul olemas. Muuseumid tegelevad vaid osaga pärandist. See on tingitud traditsioonilisest valdkondade jaotusest pärandiinstitutsioonide vahel. Kuid täpselt samamoodi, nagu on pidevalt suurenenud pärandi hulka loetavate objektide ja nähtuste ring, on paralleelselt kasvanud ka selle pärandi osakaal, millega muuseumid tegelevad. Pärandiobjektide ja -nähtuste käsitlusvaldkonnad muuseumides ja teistes pärandiinstitutsioonides kattuvad oma olemuselt suuresti. Kindlasti näeme üha suurenevat konvergentsi pärandiinstitutsioonide vahel.

Muuseumid toimivad mitmel ühiskonna organiseerituse tasemel. Omavalitsuste ja riigi tasandil pärandi loomine on pikka aega olnud objektipõhine, mujal maailmas on alates 1980. aastatest hakatud üle minema väärtuspõhisele pärandiloomele, Eestis on see protsess käimas. Väärtuste määratlemine on siiski suuresti ekspertide pärusmaa, mis muudab aga omakorda keerukamaks ülemineku inimesekesksele pärandihaldusele. 
Inimesekeskne pärandihaldus on dünaamiline sotsiaalne protsess, mis paratamatult sisaldab erinevaid lähenemisi pärandi väärtustele. Muuseumid on sellise multiperspektiivse vaate esitamisel jõudnud kaugemale kui näiteks muinsuskaitse. Kindlasti on selle üheks põhjuseks asjaolu, et muuseumivaldkond ei ole nii jäigalt seadusandlikult määratletud ja bürokraatlikult reguleeritud kui muinsuskaitse. Pärandi haldamine seisneb selle pidevas uuesti loomises ja jällegi on just muuseumid need paigad, kus selline uuesti loomine on loomuomane (Lukas 2018). Muuseumis asetatakse objekte pidevalt uude konteksti, iga näitus on objekti uus interpreteering ja selle käsitlemine uuest perspektiivist lähtudes. Täpselt sama protsess toimub ju ka kõigi muude pärandiobjektide ja -nähtustega, võib-olla küll vähem kontrollitavas ja jälgitavas kontekstis.

Pärandi haldamise otsustavaks küsimuseks on jätkusuutlike ja enam kaasavate haldusmeetodite kasutuselevõtt. Museoloogiline teooria ja muuseumide praktika pakub mitmeid sellekohaseid näiteid. Inimesekeskne pärandihaldus tähendab ennekõike tulevikku suunatud väärtuse ja tähenduse loomist. Pärandi haldamine on nüüdisaja sotsiaalse ja kultuurilise reaalsuse reinterpreteerimine, kasutades selleks valitud minevikutõlgendusi. Selle eesmärgiks on oleviku muutmine soovitavaks tulevikuks. Seejuures on oluline pidada silmas nii pärandi liike kui ka ühiskonna tasandeid.

KURMO KONSA (PhD) on Tartu Ülikooli ajaloo ja arheoloogia instituudi dotsent arhiivinduse osakonnas ja Kõrgema Kunstikooli Pallas professor konserveerimise erialal. Põhiliseks uurimisvaldkonnaks on objektide säilitamine mäluasutustes ja pärandiuuringud.

KAIE JEESER (MA) on Tartu Linnamuuseumi peavarahoidja, 2018. aastast Eesti Muuseumiühingu juhatuse liige ja 2019. aastast EMÜ Koguhoidjate ühenduse esimees. Alates 2007. aastast on ta ICOM CIDOCi liige ja 2013. aastast juhatuse liige. Tegevusvaldkond on kogude haldamine ning museaalide dokumenteerimine ja info vahendamine. 


\section{Kirjandus}

A Museum Studies Approach to Heritage. 2019. Toim Sheila Watson, Amy Jane Barnes, Katy Bunning. Oxon, New York: Routledge.

Absalyamova, Albina; Absalyamov, Timur; Absayamova, Svetlana. 2015. Private museums as form of preservation of cultural heritage. - Procedia. Social and Behavioral Sciences 188: 218-221.

Alivizatou, Marilena. 2008. Contextualizing intangible cultural heritage in heritage studies and museology. - International Journal of Intangible Heritage 3: 44-54.

Asworth, Gregory; Tunbridge, John. 1996. Dissonant Heritage: The Management of the Past as a Resource in Conflict. Chichester: Wiley.

Babić, Darko. 2016. Bridging the boundaries between museum and heritage studies. Museum International 68 (1-2): 15-28.

Candlin, Fiona. 2015. Micromuseology: An Analysis of Small Independent Museums. London: Bloomsbury Academic.

Candlin, Fiona. 2012. Independent museums, heritage and the shape of museum studies. Museum and Society 10 (1): 24-41.

Crow, Graham. 2011. Community. - The Concise Encyclopedia of Sociology. Toim George Ritzer ja J. Michael Ryan. Chichester: Blackwell Publishing.

Davis, Peter. 1999. Ecomuseums: A Sense of Place. London: Leicester University Press.

During, Roel. 2011. European Heritage Discourses, a Matter of Identity Construction? - Cultural Heritage and Identity Politics. Toim Roel During (Silk Road Research Foundation, 2011), 17-18, http://slkrd.files.wordpress. com/2011/o9/978-94-6173-076-3-cultural-e1. pdf (viimati külastatud 25.03.2019).

Euroopa Liidu toimimise lepingu konsolideeritud versioon. 2010. https://www.ecb.europa.eu/ ecb/legal/pdf/oj_c_2016_202_full_et_txt.pdf

Harrison, Rodney. 2013. Heritage: Critical Approaches. London, New York: Routledge.

Hayashi, Nao. 2015. Museums and world heritage sites: a path to shared history. - Museum International 65 (1-4): 123-134.
Hayashi-Denis, Nao. 2010. Community Based Approach to Museum Development in Asia and Pacific for Culture and Development. Paris: UNESCO Publishing.

Hewison, Robert. 1987. The Heritage Industry: Britain in a Climate of Decline. London: Methuen Publishing.

ICOMi muuseumide eetikakoodeks. 2014. http://www.icomeesti.ee/files/ICOMi_eetikakoodeks.pdf (viimati külastatud 25.03.2019).

Knell, Simon. 2004. Altered values: searching for a new collecting. - Museums and the Future of Collecting. Toim Simon Knell. Aldershot, Burlington: Ashgate, 1-46.

Konsa, Kurmo. 2014. Laulupidu ja verivorst: 21. sajandi vaade kultuuripärandile. Tartu: Tartu Kõrgem Kunstikool.

Kreps, Christina. F. 2003. Liberating Culture. Cross-cultural Perspectives on Museums, Curation and Heritage Preservation. London: Routledge.

Lorente, Jesús-Pedro. 2012. The development of museum studies in universities: from technical training to critical museology. - Museum Management and Curatorship 27 (3): 237-252.

Lowenthal, David. 1996. The Heritage Crusade and the Spoils of History. London: Viking.

Lukas, Scott A. 2018. Heritage as remaking: locating heritage in the contemporary world. - The Oxford Handbook of Public Heritage theory and practice. Töim Angela M. Labrador, Neil Asher Silberman. New York: Oxford University Press, 155-167.

Muinsuskaitseseadus. 2019. https://www.riigiteataja.ee/akt/123032015128 (viimati külastatud 25.03.2019).

Muuseumikogu täiendamise ja kultuuriväärtusega asja muuseumisse hoiule võtmise kord. 2013. https://www.riigiteataja.ee/akt/110072013068 (viimati külastatud 25.03.2019).

Muuseumiseadus 2019. https://www.riigiteataja. ee/akt/110072013001 (viimati külastatud 25.03.2019).

National Trust for Historic Preservation. 2017. Preservation for People: A Vision for Future. Washington DC: National Trust for Historic Preservation. 
Osalus muuseumides. 2014. Koostanud Pille Runnel. Tartu: Eesti Rahva Muuseum.

Rivard, René. 1984. Opening up the Museum Toward a New Museology: Ecomuseums and "Open” Museums. Quebec City: published by the author.

Smith, Laurajane. 2006. Uses of Heritage. London, New York: Routledge.

The Athens Charter for the Restoration of Historic Monuments, 1931. ICOMOS. https://www.icomos.org/en/167-the-athens-charter-for-therestoration-of-historic-monuments (viimati külastatud 25.03.2019).

The Burra Charter, 2013. The Australia ICOMOS Charter for Places of Cultural Significance. Australia ICOMOS. https://australia.icomos. org/wp-content/uploads/The-Burra-Charter-2013-Adopted-31.10.2013.pdf

The Nara Document on Authenticity. 1994. ICOMOS. https://www.icomos.org/charters/ nara-e.pdf (viimati külastatud 25.03.2019).

Turner, Hannah. 2015. Decolonizing ethnographic documentation: a critical history of the early museum catalogs at the Smithsonian's National Museum of Natural History. - Cataloging \& Classification Quarterly 53 (5-6): 658-676.
UNESCO 2003. Convention for the Safeguarding of the Intangible Cultural Heritage. Paris: UNESCO.

Veneetsia harta. https://et.wikipedia.org/wiki/Veneetsia_harta (viimati külastatud 25.03.2019).

Vergo, Peter. 1989. The New Museology. London: Reaktion Books.

Vint, Tiina. 2017. Kuidas hinnata asjade väärtust? - Eesti Rahva Muuseumi ajaveeb, 2. mai 2017. https://blog.erm.ee/?p=9851 (viimati külastatud 25.03.2019).

Watson, Sheila; Barnes, Amy Jane; Bunning, Katy. 2019. Preface - A Museum Studies Approach to Heritage. Toim Sheila Watson, Amy Jane Barnes, Katy Bunning. Oxon, New York: Routledge, xxii-xxiii.

Ülemaailmse kultuuri- ja looduspärandi kaitse konventsioon. 1972. https://www.riigiteataja.ee/akt/13118943 (viimati külastatud 25. 03.2019). 


\title{
Summary:
}

\section{Museum and heritage: towards a people-centered heritage management}

\author{
Kurmo Konsa \\ Kaie Jeeser
}

Museums are memory institutions. They serve to collect, study, preserve and mediate to the public culturally valuable objects related to human beings and their living environment. They bolster the formation of social, communal and family identities; they function as public memory institutions, supporting education and scientific research and, of course, museums provide entertainment and recreation. In this article, we look at museums from the perspective of heritage studies, and for our analysis, we use the following three dimensions: heritage objects, levels of society and processes of heritage management. Our objective is to present a conceptual framework which would highlight more clearly the connections between heritage and museums and which would lay a foundation for interlinking some theoretical concepts from heritage studies and museology and help to improve practical heritage management.

Museums and heritage are closely, if not inextricably, linked. A museum's connection with heritage has always been one of the important features that defines it. At the same time, the relationships between various heritage institutions and their links with broader heritage paradigms have not been sufficiently researched. Since the second half of the 2oth century, the number of objects and phenomena considered to be heritage has dramatically increased. Museums endeavor to keep pace with these changes, and thus more new museums are being established and the range of collection items is expanding.

For a long time, discussions of museums encompassed only nationallevel museums. This is due to the fact that national museums are the oldest of such institutions to have emerged, and on the other hand, it is museums at the national level that have attained the most influential position in the heritage landscape. At the same time museologists have paid rather scant attention to museum institutions at other levels. Private museums and personal collections have not received sufficient museological consideration even though they form a significant amount of social heritage and are the most natural to people, and often the most important for them too. Likewise, community and local government memory institutions have only recently become of interest to museology, which is also the case even in the context of world heritage. All activities connected 
to heritage may be summed up with the term 'heritage management'. Heritage management incorporates principles and practices connected to the identification, preservation, documentation, interpretation and presentation of objects of historical, natural, scientific or other interest. The processes of heritage management can be grouped according to their focus: object-based, value-based and people-centered. These approaches do not follow a specific chronological order and are not necessarily exclusive of one another. Although they come in a certain chronological sequence, all the approaches are currently used depending on the context and purpose of the inquiry. These approaches reflect an increasingly more comprehensive and integrated treatment of heritage management.

People-centered heritage management is a dynamic social process which necessarily includes diverse perspectives on the value of the heritage. Museums have made much better progress in producing multi-perspective views than heritage conservation has by comparison. One of the reasons is that the museum field is not as rigidly defined by law or regulated by bureaucracy as heritage conservation is.

Heritage management consists of a continuous re-creation of the heritage, and here again, museums are the places where such re-creations characteristically occur. It is in museums that we continually place objects in new contexts and examine how that impacts people. Each exhibition is a new interpretation of the object, offering a treatment of it from a novel perspective. In fact the exact same process takes place with regard to all other heritage objects and phenomena, but perhaps within less controllable and observable contexts.

A key issue for heritage management is the introduction of sustainable and more inclusive management methods. Museological theory and museum practice offer several examples here. People must be involved in the management of heritage at each stage, starting from the definition of what it precisely is and ending with its interpretation. It is important to develop and implement relevant practices. The idea of a participatory museum has made significant gains in this direction.

People-centered heritage management entails, above all, the creation of future-oriented values and meanings. In a sense, the perspective must shift from the past to the future. Heritage is not a thing of the past, but of the future. It is a social and cultural resource that forms the basis for our plans for the future. We believe that this is the primary function of the heritage. Heritage management is the reinterpretation of contemporary social and cultural realities by using interpretations of the past selected for this purpose. Its objective is to change the present into a desirable future. Here it is important to take into account different types of heritage as well as different levels of society. Heritage stories must be like a symphony that incorporates all the participants from all of the different levels of society. 


\title{
человеком в центре внимания
}

\author{
Курмо Конса \\ Кайе Еэзер
}

Музеи - это институты памяти.

В них собираются, сохраняются, изучаются, выставляются на обозрение объекты, связанные с человеком и его жизненной средой и представляющие культурную ценность. Они содействуют формированию социальной, общинной и семейной идентичности, функционируют в качестве институтов памяти и поддерживают образование и научную деятельность. Также в музеях предлагаются различные возможности развлечься и провести досуг.

В данной статье музеи рассматриваются с точки зрения изучения наследия. Свой анализ мы проводим в трёх измерениях объекты наследия, социальные уровни и процессы управления наследием. Цель работы заключается в представлении концептуальных рамок для лучшего выявления связей между наследием и музеями и создания основы для сопряжения изучения наследия и музееведческих теоретических понятий, а также для лучшей организации управления наследием.
Музеи очень тесно, даже неразрывно связаны с наследием. Эта связь всегда выступает в качестве одного из важнейших признаков при определении музеев. В то же время взаимоотношения различных учреждений, занимающихся вопросами наследия, и их связь с более широкими парадигмами наследия изучены недостаточно. Начиная со второй половины XX века стремительно увеличивалось количество объектов и явлений, относимых к наследию. Музеи стараются шагать в ногу с этими изменениями, открываются новые музеи, ширится круг собираемых объектов.

Рассмотрении вопросов, касающихся музеев, на протяжении долгого времени ограничивалось лишь учреждениями государственного уровня. Это было обусловлено тем, что они образовались раньше других, и именно музеи этого уровня занимают наиболее влиятельное положение в сфере наследия. Музееведческое внимание к музеям других уровней до сих пор было довольно скромным. Частные музеи 
и личные коллекции недостаточно хорошо изучены с точки зрения музееведения, хотя личное наследие образует довольно большую часть наследия общества, к тому же оно наиболее близко людям, а зачастую и наиболее важно. Общинные музеи и институты памяти местных самоуправлений также лишь недавно попали в круг интересов музееведения. И даже в контексте мирового наследия внимание к институтам памяти стало уделяться лишь недавно. Всю деятельность, связанную с наследием, можно обобщить в понятии «управление наследием». Управление наследием (heritage management) охватывает принципы и формы деятельности, связанные с выявлением, сохранением, документированием, толкованием и демонстрацией объектов, мест и явлений, представляющих историческую, природную, научную и прочую ценность. Процессы управления наследием могут ставить в центре внимания человека, объекты или ценности. Разные типы управления не обязательно выступают в хронологическом порядке, исключая при этом друг друга. Они действительно имеют определённую временную последовательность, но в настоящий момент используются все типы в зависимости от контекста. Выбор типа управления зависит также от цели. Данные подходы выражают всё более объемлющее и комплексное рассмотрение управления наследием.
Управление наследием с человеком в центре внимания является динамичным социальным процессом, содержащим различные взгляды на ценность наследия. В представлении такого многостороннего подхода музеи ушли дальше, чем, например, охрана памятников старины. Безусловно, одной из причин этого является то обстоятельство, что музейная сфера не настолько жёстко отрегулирована в законодательном и бюрократическом плане, как охрана памятников старины.

Управление наследием заключается в постоянном создании наследия заново. Как раз музеи являются тем местом, которому свойственен процесс постоянного созидания. В музее мы постоянно помещаем объекты в новые контексты и изучаем, как это влияет на людей. Каждая выставка является новой интерпретацией объектов, их рассмотрением с иных сторон. Такой же процесс происходит со всеми другими объектами и явлениями наследия, быть может только в менее контролируемых и наблюдаемых контекстах.

Решающим вопросом в управлении наследием является внедрение жизнеспособных и более привлекающих методов управления. В теории музейного дела и в практике музеев имеются подобные примеры. Люди должны принимать участие в управлении наследием на всех его этапах, начиная с определения наследия 
и заканчивая его интерпретацией. Важно разработать соответствующие практики и воплотить их в жизнь. Значительное содействие в этом направлении оказала идея музея участия.

Управление наследием с человеком в центре внимания означает, прежде всего, создание ценностей и смыслов, устремлённых в будущее. В некотором смысле это означает разворот от прошлого к будущему. Наследие не есть что-то из прошлого, это нечто, направленное в будущее. Это - социальный и культурный ресурс, служащий основой для планирования будущего. И это самая важная функция наследия вообще. Управление наследием - это реинтерпретация социальных и культурных реалий современности с использованием определённых толкований прошлого с целью обратить настоящее в желаемое будущее. При этом важно учитывать как различные виды наследия, так и разные уровни в обществе. Наследие должно быть похоже на симфонию, увлекающую всех участников на всех социальных уровнях. 